\title{
UPAYA MENINGKATKAN AKTIVITAS DAN HASIL BELAJAR SISWA DENGAN MENERAPKAN PENDEKATAN RESOURCE BASED LEARNING PADA MATERI BANGUN RUANG SISI DATAR
}

\author{
${ }^{1}$ Rahman Ramadhan Yusuf, ${ }^{2}$ M. Fachruddin S., ${ }^{3}$ Nurul Astuty Yensy B. \\ 1,2,3 Program Studi Pendidikan Matematika JPMIPA FKIP UNIB
}

Email: ${ }^{1}$ kampung.ramadan@gmail.com, ${ }^{2}$ m.fachruddin.s@gmail.com, ${ }^{3}$ nurulastutyyensy@yahoo.com

\begin{abstract}
Abstrak
Penelitian ini bertujuan untuk mengetahui cara meningkatkan aktivitas belajar dan hasil belajar siswa dengan menerapkan pendekatan Resource Based Learning. Penelitian ini merupakan Penelitian Tindakan Kelas dengan teknik pengumpulan data melalui lembar observasi aktivitas belajar dan tes hasil belajar. Subjek dalam penelitian adalah kelas VIII 2 SMP Negeri 3 Kota Bengkulu tahun ajaran 2016/2017 berjumlah 40 siswa. Hasil penelitian menunjukkan peningkatan aktivitas belajar siswa yang dilakukan dengan belajar berbagai sumber seperti, LKPD, buku-buku matematika, sumber internet dan alat peraga. Peningkatan aktivitas belajar siswa dapat dilihat dari skor rata-rata lembar observasi aktivitas belajar siswa pada siklus I sampai siklus III yaitu 23,50 (cukup aktif); 26,67(cukup aktif); 30(aktif). Hasil belajar siswa ditingkatkan dengan cara menggunakan LKPD dan alat peraga. Peningkatan hasil belajar siswa dilihat dari nilai rata-rata siswa pada siklus I sampai siklus III yaitu 71,06; 81,00; 84,02 dengan persentase ketuntasan belajar yaitu 50\%; 77,50\%; 87,50\%.
\end{abstract}

Kata Kunci : pendekatan resource based learning, aktivitas belajar, hasil belajar

\begin{abstract}
The study aims to find out how to improve learning activities and student learning outcomes by applying Resource Based Learning approach. This research is a Classroom Action Research with data collection technique through observation sheet of learning activity and test of learning result. Subjects in the study were Class VIII 2 SMP Negeri 3 Bengkulu City academic year 2016/2017 amounted to 40 students. The results showed an increase in student learning activities conducted by learning various sources such as, LKPD, math books, internet resources and props. Increased student learning activity can be seen from the average score of observation sheet of student learning activities on the cycle I to cycle III is 23.50 (active enough); 26.67 (active enough); 30 (active). Student learning outcomes are improved by using LKPD and props. Improvement of student learning outcomes seen from the average value of students in the cycle I until the third cycle of 71.06; 81.00; 84.02 with the percentage of learning mastery that is 50\%; 77.50\%; $87.50 \%$.
\end{abstract}

Keywords: resource based learning approach, learning activities, learning outcomes

\section{PENDAHULUAN}

Proses belajar matematika yang baik adalah bahwa guru harus mampu menerapkan suasana yang dapat membuat murid bersemangat terhadap persoalan yang akan dihadapi sehingga mereka mampu memahami konsep dan memecahkan persoalan yang ada. Berdasarkan wawancara dengan guru matematika di SMP Negeri 3 Kota Bengkulu fakta di lapangan menunjukkan rendahnya aktivitas dan hasil belajar siswa. Menurut Sardiman (2011:100) aktivitas belajar adalah aktivitas yang bersifat fisik maupun mental. Dalam kegiatan belajar, kedua aktivitas itu harus selalu berkait. Sedangkan menurut Kunandar (2011:277) yang menyatakan bahwa aktivitas belajar adalah keterlibatan peserta didik dalam bentuk sikap, pikiran, perhatian, dan aktivitas dalam kegiatan pembelajaran untuk menunjang keberhasilan dan memperoleh manfaat dari proses belajar mengajar tersebut. Aktivitas belajar yang diteliti pada penelitian ini meliputi; 1)Visual activities, 2)Oral activities, 
3)Listening activities,

5)Drawing activities,

7)Mental activities.

Menurut Suprijono (2009:5-7) hasil belajar adalah perubahan perilaku secara keseluruhan meliputi pola-pola perbuatan, nilainilai, pengertian-pengertian, sikap-sikap, apresiasi dan keterampilan. Sedangkan menurut Paizaluddin dan Ermalinda (2014:212) mengungkapkan bahwa hasil belajar adalah hasil yang dicapai peserta didik setelah melalui proses pembelajaran yang dapat dilihat dari nilai rapor yang menunjukkan tingkat kemampuan peserta didik dalam menguasai materi pelajaran.

Berdasarkan observasi, guru matematika di SMP Negeri 3 Kota Bengkulu untuk beberapa materi belum menggunakan LKPD dalam proses pembelajaran terkhususnya materi bangun ruang sisi datar. LKPD adalah lembar-lembar yang berisi tugas yang harus dikerjakan peserta didik untuk menguasai kompetensi yang dipersyaratkan (Sulastri, 2014:13). Menurut Depdiknas (2008:13) lembar kegiatan siswa (student worksheet) adalah lembaran-lembaran berisi tugas yang harus dikerjakan oleh peserta didik. LKS merupakan suatu bahan ajar cetak berupa lembar-lembar kertas yang berisi materi, ringkasan, dan petunjuk-petunjuk pelaksanaan tugas pembelajaran yang harus dikerjakan oleh peserta didik, yang mengacu pada kompetensi dasar yang harus dicapai (Prastowo, 2011:204).

Rendahnya pencapaian aktivitas belajar dan hasil belajar siswa disebabkan oleh penggunaan metode, pendekatan dan strategi yang kurang sesuai. Selain itu juga guru kurang maksimal dalam pemanfaatan sumber belajar dan media yang tersedia yang mana hanya memanfaatkan sumber buku paket yang ada. Salah satu pendekatan pembelajaran yang dapat diterapkan guna memanfaatkan sumber belajar dan dapat mendorong peran aktif siswa dalam pembelajaran adalah pendekatan Resource Based Learning atau belajar berdasarkan sumber.

Menurut Suryosubroto (2013:215) belajar berdasarkan sumber (Resource Based Learning) adalah suatu pendekatan yang dirancang untuk memudahkan siswa dalam mengatasi keterampilan siswa tentang luas dan keanekaragaman sumber-sumber informasi yang dapat dimanfaatkan untuk belajar. Resource
Based Learaning yang dimaksud adalah segala bentuk belajar yang langsung menghadapkan murid dengan suatu atau sejumlah sumber belajar secara individual atau kelompok dengan segala kegiatan belajar yang bertalian dengan itu, jadi bukan dengan cara konvensional dimana guru menyampaikan bahan pelajaran kepada murid (Nasution, 2013:18).

Menurut Baswick dalam buku Suryosubroto (2013:216) pembelajaran berdasarkan sumber "Resource Based Learning" melibatkan keikutsertaan secara aktif dengan berbagai sumber (orang, buku, jurnal, surat kabar, multimedia, web, dan masyarakat), dimana para siswa akan termotivasi untuk belajar dengan berusaha meneruskan informasi sebanyak mungkin. Sumber belajar yang digunakan dalam penelitian ini adalah buku paket, 2 buku pelajaran matematika terbitan nasional, sumber internet dan alat peraga.

Dalam penelitian ini guru memanfaatkan sumber internet untuk mencari sumber informasi yang dibutuhkan dalam proses pembelajaran pada materi bangun ruang sisi datar. Dimana siswa diberi tugas untuk mencari sumber informasi di internet mengenai materi yang akan dipelajarinya di sekolah. Guru juga turut menyediakan sumber informasi di internet untuk membantu dan menambah wawasan guru. Dengan adanya sumber belajar dari internet diharapkan siswa dapat mengetahui informasi mengenai materi secara luas sehingga dapat melatih kemandirian siswa dalam belajar dan menanamkan konsep di pola pikir mereka bahwa betapa pentingnya belajar dari berbagai sumber yang ada. Pada penelitian ini guru harus mengecek sumber kebenaran dari sumber internet yang siswa bawa. Hal ini dilakukan agar siswa dapat belajar dari sumber-sumber tepercaya sehingga apa yang dipahami siswa merupakan informasi yang tepat.

Sedangkan media pembelajaran adalah sebuah alat yang berfungsi dan digunakan untuk pesan pembelajaran (Sundayana, 2015:6). Menurut Ruseffendi (1992), alat peraga adalah alat yang menerangkan atau mewujudkan konsep matematika, sedangkan pengertian alat peraga matematika menurut Pramudjono (1995), adalah benda konkret yang dibuat, dihimpun atau disusun secara sengaja digunakan untuk membantu menanamkan atau mengembangkan 
konsep matematika (Sundayana, 2015:7). Dalam penelitian ini, media pembelajaran yang digunakan adalah media alat peraga. Dimana alat peraga yang membantu siswa menemukan konsep mencari luas dan volume dari kubus, balok, prisma, dan limas.

Sekolah SMP Negeri 3 Kota Bengkulu telah menerapkan kurikulum 2013 sehingga langkahlangkah penerapan Resource Based Learning dalam penelitian ini menggunakan syntax pendekatan saintifik. Adapun syntax pendekatan sainifik menurut Hosnan (2014:29) ada 5 tahap yaitu mengamati, menanya, mengumpulkan informasi, mengasosiasi, dan mengomunikasikan.

Pada tahap pertama yaitu mengamati. Pada kegiatan ini siswa mengamati dan membaca informasi yang ada pada LKPD. Siswa juga membaca informasi tambahan dari berbagai sumber belajar yang telah disediakan seperti buku paket, buku matematika terbitan nasional dan sumber internet.

Pada tahap kedua yaitu menanya. Pada kegiatan ini siswa membuat pertanyaan dari informasi yang telah mereka amati pada LKPD. Pertanyaan ini bertujuan untuk menambah informasi atau wawasan siswa atas apa yang telah mereka amati. Pada kegiatan ini guru perlu mengarahkan dan membimbing siswa untuk membuat pertanyaan sampai ke tingkat dimana siswa mampu membuat pertanyaan secara mandiri.

Pada tahap ketiga yaitu mengumpulkan informasi. Pada tahap kegiatan mengumpulkan informasi merupakan tindak lanjut dari bertanya. Kegiatan ini dilakukan dengan menggali dan mengumpulkan informasi dari berbagai sumber melalui berbagai cara. Pada kegiatan ini siswa bersama anggota kelompoknya mencari informasi dari berbagai sumber yang telah disediakan seperti buku paket, buku-buku pelajaran matematika terbitan nasional dan sumber internet. Pada kegiatan ini mencakup indikator siswa dapat menyatakan ulang suatu konsep.

Pada tahap keempat yaitu mengasosiasi. Pada kegiatan pembelajaran sebagaimana disampaikan dalam Permendikbud Nomor 81a Tahun 2013, adalah memproses informasi yang sudah dikumpulkan baik terbatas dari hasil kegiatan mengumpulkan maupun hasil dari kegiatan mengamati dan kegiatan mengumpulkan informasi. Pengolahan informasi yang dikumpulkan dari yang bersifat menambah keluasan dan kedalaman sampai kepada pengolahan informasi yang bersifat mencari solusi dari berbagai sumber yang memiliki pendapat yang berbeda sampai kepada yang bertentangan.

Pada tahap kelima yaitu mengomunikasikan. Pada kegiatan ini guru meminta siswa untuk mempresentasikan hasil diskusi LKPDnya di depan kelas. Kemudian anggota kelompok yang lain bertanya dan menanggapi hasil diskusi LKPD. Pada kegiatan ini terjadi interaksi guru dengan siswa, siswa dengan siswa.

Pada penelitian ini, materi yang dipilih adalah materi SMP di kelas VIII semester genap pada pokok bahasan bangun ruang sisi datar sesuai dengan standar kompetensi (SK) dan Kompetensi Dasar (KD) pada kurikulum 2013. Berdasarkan latar belakang di atas, maka penulis menggunakan bahan ajar dengan pendekatan Resource Based Learning. Bahan ajar tersebut berupa LKPD, buku paket, 2 buku pelajaran matematika terbitan nasional, sumber internet dan alat peraga. Oleh karena itu, dilakukan penelitian tentang "UPAYA MENINGKATKAN AKTIVITAS DAN HASIL BELAJAR SISWA DENGAN MENERAPKAN PENDEKATAN RESOURCE BASED LEARNING PADA MATERI BANGUN RUANG SISI DATAR".

Berdasarkan latar belakang di atas, maka rumusan masalah dalam penelitian ini adalah :

1. Bagaimana cara menerapkan pendekatan Resource Based Learning pada materi bangun ruang sisi datar agar dapat meningkatkan aktivitas belajar matematika siswa kelas VIII SMPN 3 Kota Bengkulu?

2. Bagaimana cara menerapkan pendekatan Resource Based Learning pada materi bangun ruang sisi datar agar dapat meningkatkan hasil belajar matematika siswa kelas VIII SMPN 3 Kota Bengkulu?

Sesuai dengan rumusan masalah yang ada, maka tujuan yang hendak dicapai dalam penelitian ini adalah:

1. Untuk mengetahui cara menerapkan pendekatan Resource Based Learning pada materi bangun ruang sisi datar agar dapat 
meningkatkan aktivitas belajar matematika siswa kelas VIII SMPN 3 Kota Bengkulu.

2. Untuk mengetahui cara menerapkan pendekatan Resource Based Learning pada materi bangun ruang sisi datar agar dapat meningkatkan hasil belajar matematika siswa kelas VIII SMPN 3 Kota Bengkulu.

\section{METODE}

Jenis penelitian yang dilakukan adalah penelitian tindakan kelas. Dimana penelitian tindakan kelas dapat juga diartikan suatu kegiatan ilmiah yang dilakukan oleh guru di kelasnya sendiri dengan jalan merancang, melaksanakan, mengamati, dan merefleksikan tindakan melalui beberapa siklus secara kolaboratif dan partisipasi yang bertujuan untuk memperbaiki atau meningkatkan mutu proses pembelajaran di kelasnya (Kunandar, 2011:46).

Dengan demikian, dapat dikatakan bahwa penelitian tindakan kelas adalah salah satu bentuk penelitian kualitatif yang dilakukan seseorang secara individual atau kelektif, yang bertujuan untuk mengubah atau memperbaiki berbagai hal tentang permasalahan yang mendesak dalam suatu komunitas atau kelompok tersebut. Penelitian tindakan kelas ini secara garis besar terdapat empat tahapan yang harus dilalui, yaitu: (1)Perencanaan; (2) Pelaksanaan;

Pengamatan; (4) Refleksi. Penelitian ini dilakukan di SMP Negeri 3 Kota Bengkulu. Penelitian ini dilakukan pada kelas VIII 2 semester genap tahun ajaran 2016/2017. Jumlah siswa-siswi di kelas VIII 2 adalah 40 orang terdiri dari 16 siswa laki-laki dan 24 siswi perempuan. Penelitian ini dilaksanakan kurang lebih dua bulan yaitu pada tanggal 3 April 2017 sampai dengan tanggal 31 Mei 2017. Instrumen yang digunakan dalam penelitian ini adalah lembar observasi aktivitas belajar siswa yang diisi oleh dua orang pengamat, yaitu guru matematika di kelas tersebut dan rekan peneliti. Kemudian hasil belajar siswa yang dinilai didapat dari nilai tes akhir yang diperoleh siswa pada setiap siklus.

Nilai Rata-Rata Hasil Belajar

$$
\bar{X}=\frac{\sum X}{\sum N}
$$

Keterangan:

$$
\bar{X}=\text { Nilai rata-rata }
$$

$\sum X=$ Jumlah semua nilai siswa

$\sum N=$ Banyaknya siswa

(Daryanto, 2014:191)

\section{Persentase Ketuntasan Belajar Klasikal}

Berdasarkan Kurikulum Tingkat Satuan Pendidikan di SMP Negeri 3 Kota Bengkulu menyatakan ketuntasan belajar untuk (a) individu: jika siswa mendapat nilai $\geq 75$, (b) klasikal: jika $80 \%$ siswa mendapat nilai $\geq 75$. Persentase ketuntasan belajar klasikal dihitung dengan menggunakan persamaan:

Keterangan:

$$
P=\frac{\sum \text { siswa yang tuntas belajar }}{\Sigma \text { siswa }} \times 100 \%
$$

P: Persentase Ketuntasan Belajar Klasikal

(Daryanto,2014 : 192)

Tabel 1. Kriteria Penilaian untuk Lembar Observasi Aktivitas Siswa

\begin{tabular}{|l|l|l|l|}
\hline No & $\begin{array}{l}\text { Kriteria } \\
\text { Penilaian }\end{array}$ & Notasi & Skor \\
\hline 1 & Kurang & K & 1 \\
\hline 2 & Cukup & C & 2 \\
\hline 3 & Baik & B & 3 \\
\hline \multicolumn{4}{|c|}{ (Modifikasi Sudjana, 2011:77) }
\end{tabular}

Tabel 2. Kriteria Skor Pengamatan untuk Lembar Observasi Aktivitas Siswa

\begin{tabular}{|l|l|}
\hline Kategori Penilaian & Kisaran Skor \\
\hline Kurang Aktif & $12 \leq \mathrm{x}<20$ \\
\hline Cukup Aktif & $20 \leq \mathrm{x}<28$ \\
\hline Aktif & $28 \leq \mathrm{x} \leq 36$ \\
\hline
\end{tabular}

Tabel 3. Kriteria Skor Interval Pengamatan Aktivitas per Aspek.

\begin{tabular}{|c|c|}
\hline $\begin{array}{c}\text { Kategori } \\
\text { Penilaian }\end{array}$ & Kisaran Skor \\
\hline Kurang Aktif & $1,00 \leq \mathrm{x}<1,67$ \\
\hline Cukup Aktif & $1,68 \leq \mathrm{x}<2,35$ \\
\hline Aktif & $2,36 \leq \mathrm{x} \leq 3,00$ \\
\hline
\end{tabular}

\section{HASIL DAN PEMBAHASAN}

\section{Hasil}

Grafik 1. Hasil Lembar Observasi Aktivitas Siswa Siklus I Sampai Siklus III 


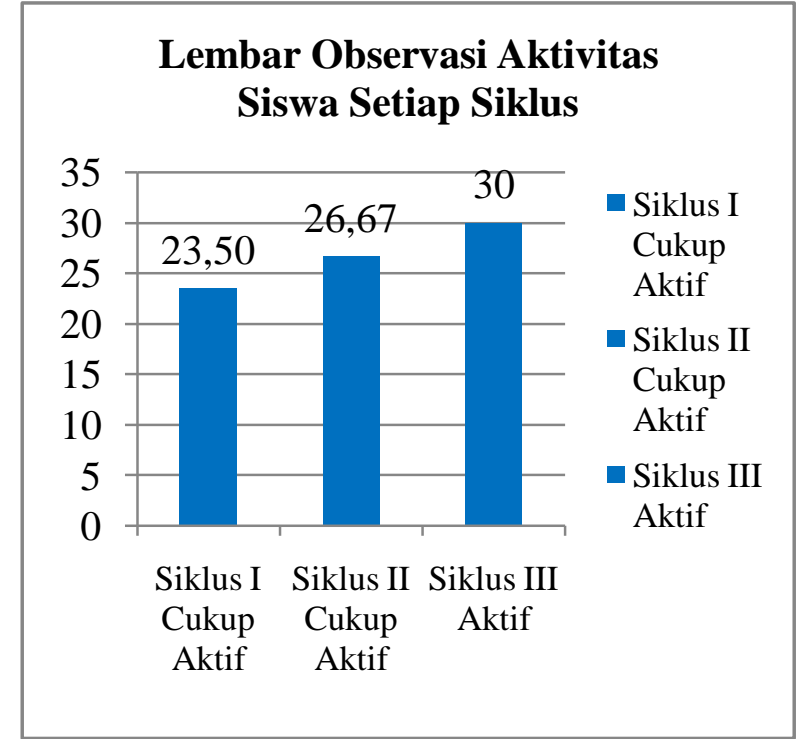

Berdasarkan hasil observasi aktivitas siswa pada pembelajaran dengan pendekatan Resource Based Learning atau belajar berbagai sumber pada siklus I sampai siklus III oleh kedua pengamat terjadi peningkatan aktivitas belajar siswa. Terlihat pada grafik diperoleh nilai ratarata skor aktivitas belajar siswa siklus I sebesar 23,50 dengan kategori cukup aktif. Pada siklus II nilai rata-rata skor aktivitas belajar siswa 26,67 dengan kategori cukup aktif. Sedangkan pada siklus III aktivitas belajar siswa dalam kategori aktif dengan rata-rata skor 30. Hal ini menunjukkan bahwa penerapan pendekatan Resource Based Learning dalam kegiatan pembelajaran dapat meningkatkan aktivitas belajar siswa.

\section{Grafik 2. Rekapitulasi Aspek Aktivitas Siswa Setiap Siklus}

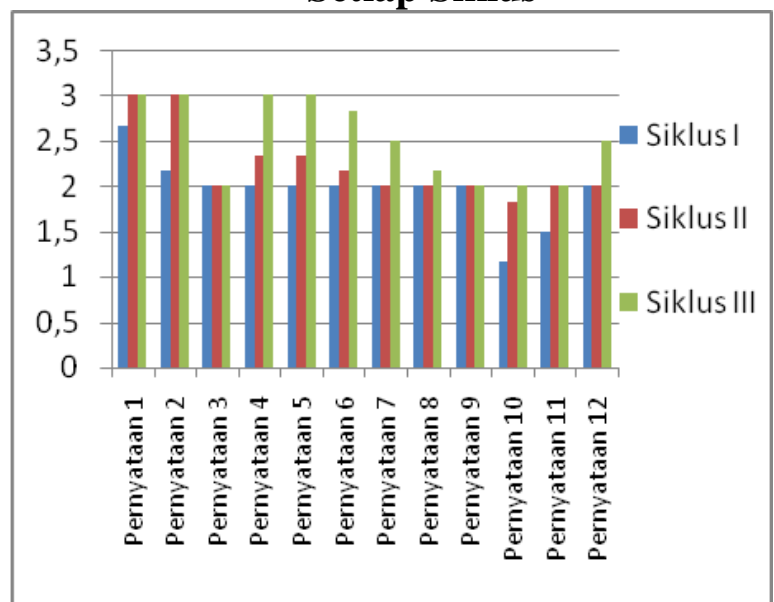

Keterangan :

Pernyataan 1 = Siswa menyimak dan memperhatikan petunjuk yang ada di LKPD.
Pernyataan 2 = Siswa membaca atau memahami informasi yang diberikan.

Pernyataan $3=$ Siswa mampu membuat pertanyaan-pertanyaan dari informasi yang telah diberikan dalam LKPD.

Pernyataan 4 = Siswa mencari berbagai sumber untuk menyelesaikan masalah atau pertanyaan yang telah dibuat.

Pernyataan $5=$ Siswa berdiskusi mencari jawaban yang paling tepat dari sumber informasi yang telah di dapat.

Pernyataan 6 = Siswa dapat menyatakan ulang suatu konsep dari sumber informasi yang ada.

Pernyataan 7 = Siswa dapat memberi contoh dan non contoh.

Pernyataan 8 = Siswa mampu mengklasifikasi objek menurut sifat-sifat tertentu sesuai dengan konsepnya. Siswa mampu mengembangkan syarat-syarat yang menentukan suatu konsep. Siswa mampu mengaplikasikan konsep.

Pernyataan 9 = Siswa menyelesaikan masalah dengan teman dalam kelompok. Siswa dapat menyajikan konsep dalam berbagai representasi dengan teman dalam kelompok.

Pernyataan $10=$ Siswa mengungkapkan ide/gagasan di depan kelas (presentasi) dan siswa lain memberikan tanggapan.

Pernyataan 11 = Siswa mampu membandingkan dan membedakan konsep-konsep.

Pernyataan 12 = Siswa menyimpulkan hasil dari diskusi yang telah dikerjakan.

Grafik 2 merupakan aspek aktivitas siswa yang akan diamati dalam proses kegiatan pembelajaran. Terlihat dari grafik bahwa rata-rata kedua belas aspek aktivitas mengalami peningkatan dari siklus I sampai siklus III.

\section{PEMBAHASAN}

Aktivitas belajar siswa pada siklus I dalam pembelajaran matematika menggunakan pendekatan Resouce Based Learning mendapat skor rata-rata yaitu 23,50 dengan kategori cukup aktif dari kedua pengamat. Hal ini disebabkan bahwa siswa belum terbiasa dalam proses kegiatan belajar berbagai sumber. Pada siklus I ini siswa juga masih belum bekerja sama dengan baik dan kurang percaya diri dalam mengungkapkan ide atau gagasannya. Pada siklus I ini siswa belum memanfaatkan sumber belajar 
dengan baik dan kurangnya kerja sama dimana siswa berkemampuan rendah lebih mengandalkan siswa berkemampuan tinggi. Pada siklus I aspek aktivitas siswa yang masih berada pada kategori kurang adalah siswa belum mampu membandingkan dan membedakan konsepkonsep, siswa belum mampu mengungkapkan ide atau gagasannya di depan kelas. Hal ini disebabkan siswa belum terbiasa dalam proses pembelajaran Resource Based Learning.

Pada siklus II aktivitas belajar siswa lebih baik dan mengalami peningkatan daripada siklus I. Hal ini dilihat dari nilai skor rata-rata observasi aktivitas belajar siswa yaitu 26,67 dengan kategori cukup aktif dari kedua pengamat. Terjadi peningkatan pada aktivitas belajar karena mereka sudah mulai terbiasa dengan proses kegiatan pembelajaran menggunakan pendekatan Resource Based learning (belajar berbagai sumber). Pada siklus II rata-rata butir aktivitas siswa berada pada kategori cukup hal ini disebabkan siswa sudah mulai terbiasa dalam proses pembelajaran Resource Based Learning dan mampu memanfaatkan sumber belajar dengan baik.

Pada siklus III, terjadinya peningkatan aktivitas belajar siswa dimana dapat dilihat dari skor rata-rata yaitu 30 dengan kategori aktif dari kedua pengamat. Pada siklus ini 6 butir aktivitas siswa berada pada kriteria cukup aktif dan 6 butir aktivitas siswa berada pada kriteria aktif. Hal ini disebabkan siswa sudah mulai terbiasa belajar mencari informasi dari berbagai sumber yang ada. Hal ini juga dipengaruhi oleh alat peraga bangun ruang dimana membantu siswa dalam proses kegiatan pembelajaran sehingga siswa dapat memahami konsep dengan baik.

Pada siklus I nilai rata-rata siswa masih rendah belum mencapai KKM dengan ketuntasan belajar siswa sebesar 50\%. Hal ini menunjukkan bahwa 20 dari 40 siswa pada tes siklus I memperoleh nilai $\geq 75$ dan 20 dari 40 siswa yang lainnya belum memenuhi indikator keberhasilan tindakan atau belum tuntas, sehingga tindakan harus dilanjutkan pada siklus II. Rendahnya hasil belajar pada tes siklus I disebabkan kurang aktif dan optimalnya kegiatan pembelajaran pada siklus I dimana siswa belum terbiasa belajar mandiri dan memanfaatkan sumber belajar yang ada. Berdasarkan pengamatan peneliti siswa-siswi kelas VIII tersebut masih mengandalkan temannya untuk mengerjakan dan terlihat belum termotivasi dalam kegiatan pembelajaran. Masih sering mengajak teman anggota kelompoknya mengobrol dan mengerjakan sesuatu hal yang tidak berhubungan dengan pelajaran. Selain itu belum terbiasanya siswa dalam kegiatan pembelajaran Resource Based Learning yang menuntut siswa berperan aktif dalam kegiatan pembelajaran juga berakibat pada rendahnya pencapaian hasil belajar siswa secara keseluruhan dimana nilai rata-rata siswa pada siklus I belum mencapai KKM $\geq 75$ yaitu sebesar 71,06.

Pada siklus II, tes hasil belajar secara keseluruhan mengalami peningkatan dimana nilai rata-rata siswa sebesar 81 mencapai indikator keberhasilan tindakan yaitu minimal nilai ratarata siswa $\geq 75$. Namun secara ketuntasan belajar klasikal siswa belum mencapai target yang diinginkan yaitu minimal $80 \%$ dari jumlah siswa memperoleh nilai $\geq 75$. Ketuntasan belajar secara klasikal pada siklus II ini sebesar 77,50\%. Hal ini menunjukan 9 dari 40 siswa yang mengikuti tes belum mencapai indikator keberhasilan tindakan atau belum tuntas. Meningkatnya hasil belajar pada siklus II menunjukkan siswa sudah mulai termotivasi untuk mengikuti kegiatan pembelajaran dengan menggunakan pendekatan Resource Based Learning. Hal tersebut juga menunjukan bahwa alternatif tindakan yang dilakukan guru juga memberikan kontribusi terhadap pencapaian hasil belajar siswa.

Pada siklus III terjadi peningkatan yang cukup signifikan terhadap nilai rata-rata siswa dan ketuntasan hasil belajar siswa pada siklus sebelumnya, dimana nilai rata-rata siswa sebesar 84,02 dan ketuntasan belajar klasikal siswa $87,5 \%$. Hal ini menunjukan ketercapaian target indikator keberhasilan tindakan siswa tercapai serta menunjukan penerapan pendekatan Resource Based Learning dapat meningkatkan hasil belajar siswa. Adapun faktor keberhasilan tersebut ialah siswa sudah mampu belajar mandiri dan bekerja sama mencari sumber informasi dari sumber-sumber yang telah tersedia, siswa juga mampu memanfaatkan alat peraga dengan baik. Berdasarkan uraian diatas maka dapat disimpulkan bahwa penerapan pendekatan Resource Based Learning dapat meningkatkan hasil belajar siswa. Peningkatan hasil belajar 
siswa dipengaruhi aktivitas siswa dalam kegiatan pembelajaran.

\section{SIMPULAN DAN SARAN}

\section{SIMPULAN}

Dari hasil penelitian yang telah dilakukan dan pembahasan yang telah diuraikan maka diperoleh kesimpulan sebagai berikut :

1. Pelaksanaan pembelajaran matematika dengan pendekatan Resource Based Learning (belajar berbagai sumber) dapat meningkatkan aktivitas belajar siswa

2. Penerapan pendekatan Resource Based Learning (belajar berbagai sumber) dapat meningkatkan hasil belajar siswa pada materi bangun ruang sisi datar di kelas VIII 2 SMP 3 Kota Bengkulu. Hal ini ditandai sebagai berikut :

a. Nilai rata-rata hasil belajar siswa kelas VIII 2 meningkat dari siklus I dengan nilai 71,06 ke siklus II dengan nilai 81 ke siklus III dengan nilai 84,02.

b. Ketuntasan belajar siswa kelas VIII 2 meningkat dari siklus I dengan nilai $50 \%$ ke siklus II dengan ketuntasan belajar 77,50\% ke siklus III dengan ketuntasan belajar $87,50 \%$.

\section{SARAN}

Berdasarkan penelitian yang telah dilakukan maka peneliti memberikan beberapa saran, yaitu :

1. Dalam melaksanakan pembelajaran dengan pendekatan Resource Based Learning hendaknya guru mampu mengelola kelas dengan baik yaitu :

a. Dengan cara mengkondisikan siswa dan membiasakan siswa untuk mencari informasi terlebih dahulu pada sumbersumber belajar yang telah disediakan seperti buku paket, 2 buku terbitan nasional dan sumber internet sebelum menanyakan permasalahan kepada guru.

b. Selalu memberitahukan kepada siswa betapa pentingnya belajar berbagai sumber sehingga ini akan melatih pola pikir siswa untuk belajar mandiri dan berusaha sendiri untuk mencari penyelesaian yang tepat atas permasalahan mereka. c. Guru harus selalu mengecek sumber kebenaran dari sumber belajar yang siswa bawa seperti halnya sumber belajar internet.

2. Guru harus selalu mengingatkan siswa untuk menggunakan alat-alat geometri dalam kegiatan menggambar jaring-jaring seperti penggaris, mistar, pensil baik dalam kegiatan belajar maupun pada saat tes siklus. Sehingga siswa mampu memahami konsep dengan tepat.

3. Dilakukan penelitian lanjutan dengan pokok bahasan yang berbeda mengingat belum optimalnya penerapan pendekatan Resource Based Learning dimana sumber belajar yang digunakan adalah buku paket, 2 buku terbitan nasional dan sumber internet. Maka untuk penelitian selanjutnya agar lebih menambah sumber-sumber belajar sehingga dapat memberikan contoh kepada guru bahwa belajar berbagai sumber sangat bermanfaat mengajarkan siswa belajar mandiri.

\section{DAFTAR PUSTAKA}

Aqib, dkk. 2009. Penelitian Tindakan Kelas. Bandung: Yrama Widya.

Arikunto, dkk. 2015. Penelitian Tindakan Kelas. Jakarta: Bumi Aksara.

Daryanto dan Dwicahyono. 2014. Pengembangan Perangkat Pembelajaran. Yogyakarta: Gava Media.

Daryanto. 2014. Penelitian Tindakan Kelas dan Penelitian Tindakan Sekolah.Yogyakarta: Gava Media.

Depdiknas. 2008. Panduan Pengembangan Bahan Ajar. Jakarta: Direktorat Jenderal Manajemen Pendidikan Dasar dan Menengah.

Dimyati dan Mudjiono. 2013. Belajar dan Pembelajaran. Jakarta: Rineka Cipta.

Hamalik, Oemar. 2012. Proses Belajar Mengajar. Jakarta: Bumi Aksara.

Hamzah dan Muhlisrarini. 2014. Perencanaan dan Strategi Pembelajaran Matematika. Jakarta: Rajawali Pers.

Hosnan,M. 2014."Pendekatan Saintifik Dan Kontekstual Dalam Pembelajaran Abad 21". Bogor : Ghalia Indonesia.

Kunandar. 2011. Penelitian Tindakan Kelas. Jakarta: Rajawali Pers. 
Musfiqon, M. 2012. Pengembangan Media dan Sumber Pembelajaran. Jakarta: Prestasi Pustakaraya.

Nasution, S. 2013. Berbagai Pendekatan dalam Proses Belajar dan Mengajar. Jakarta: Bumi Aksara.

Paizaluddin dan Ermalinda. 2014. Penelitian Tindakan Kelas. Bandung: Alfabeta.

Prastowo, Andi. 2013. Panduan Kreatif Membuat Bahan Ajar Inovatif. Jogjakarta: DIVA Press.

Sadirman. 2011. Interaksi \& Motivasi Belajar Mengajar.Jakarta: Rajawali Pers.

Shadiq, Fadjar. 2014. Pembelajaran Matematika. Yogyakarta: Graha Ilmu.

Sodjadi, R. 2000. Kiat Pendidikan Matematika di Indonesia. : Direktorat Jenderal Pendidikan

Sudijono, Anas. 2008. Pengantar Evaluasi Pendidikan.Jakarta: PT RajaGrafindo Persada.

Sudjana, Nana. 2011. Penilaian Hasil Proses Belajar Mengajar. Bandung: PT Remaja Rosdakarya.

Sudjana. 2005. Metoda Statistika.Bandung: Tarsito.

Sulastri. 2014. Pembelajaran Muatan Lokal Pendidikan Lingkungan Hidup dengan Model Pembelajaran Group Investigation untuk SMA/MA.MAN 2 Probolinggo.

Sundayana, Rostina. 2015. Media dan Alat Peraga dalam Pembelajaran Matematika.Bandung: Alfabeta.

Suprijono, Agus. 2014. Cooperative Learning. Yogyakarta: Pustaka Belajar.

Suryosubroto, B. 2013. Proses Belajar Mengajar di Sekolah. Jakarta: Rineka Cipta.

TeknologiPendidikan.Net. 2008. Belajar Berbasis Aneka Sumber, (online),(www.teknologipendidikan.net/2 008/09/04/belajar-berbasis-anekasumber/), diakses 18 Maret 2017). 